\title{
Intertextual relations in the judgment of the court of appeal
}

\author{
Natalia N. Udina - Alexey B. Kostromin - Kamo P. Chilingaryan - Elena \\ P. Kalashnikova
}

DOI: 10.18355/XL.2018.11.01.25

\begin{abstract}
The relevance of the research on intertextual relations in legal discourse is due to the growing interest in the legal language functions, criticism of its complexity and an important role legal language acquires in professional communication and social relations. The article looks into intertextual relations of a particular legal genre, the court of appeal judgment, with the view of analyzing intertextual devices, their linguistic forms, and various functions they perform in the text and discourse. The notion of intertextuality and its use in specialized discourse have been considered from discourse analysis perspective, its theory and methods, focusing on linguistic and social aspects, taking into account both explicit and implicit manifestation of intertextuality. The studies revealed that intertextual relations are very complicated and intensive and are basic to the drafting of the court judgment. They impact the structure of the text of the court of appeal judgment. Some intertextual devices typical of this genre are not found in other genres, some devices acquire specific forms and functions. The research outcomes bear academic and practical relevance for educators, law specialists and translators, providing insight into the linguistic and semantic structuring of legal texts and tools for the text of court judgment analysis and translation.
\end{abstract}

Key words: intertextuality, court judgment, discourse approach, intertextual devices, linguistic forms, discourse functions

\section{Introduction}

Specialized texts have been characterized by some particular features such as specific terminology, complex concepts, quotations and other references which often interfere with text comprehension and interpretation. Intertextuality of legal texts has received a particular interest due to raising linguistic awareness of law specialists in various domains of law and intensifying relations across languages and cultures.

The notion of intertextuality, relations between texts, used at first in the analysis of literary texts, later was applied to the analyses of specialized discourse. Intertextuality of specialized texts differs from intertextuality of literary texts in that it is pragmatic, serves professional and social functions and is intended for particular results. Due to these pragmatic considerations intertextuality is predominantly explicit. The referred texts are often required to be identified and located. The awareness of intertextual relations is equally important for both producer and receiver of the text.

Legal discourse is represented by various genres which reveal diverse types of intertextual devices, not common for other discourses. They do not only relate legal texts to previous legislation but set up the specific relationship between texts or parts of the text, performing numerous functions. Though law specialists may find no problems with intertextual links, because of training and experience, for those outside a professional law community, they could present difficulties in interpretation and understanding of texts (Bhatia, 1998).

In this respect, the specifics of intertextual relations have to be introduced into the educational context of those professions which make intensive use of texts, legal translators in particular. The forms and functions of intertextual devices in legal texts remain not fully described with the view of studying them in professional 
perspectives. The most widely used forms signaling intertextual relations are citations, reported speech and other references.

The present study focuses on the intertextual relations of the particular legal genre, the judgment of the court of appeal. The main function of the court of appeal is to review the judgments of the lower courts and to find out whether the ruling was erroneous. This sophisticated process presupposes analyzing various laws and other texts and providing judgment. Judgments are written texts, approached from the position of discourse analysis, they have been considered as legal and social actions (Fairclough, 1992). Intertextuality is a very specific feature of court judgments. The text of the judgment includes interrelations of various writings, legal acts, judges' opinions, precedent cases, other judgments, court orders and others.

\section{Literature Review}

The development of the theory of intertextuality can be traced back to the works of Russian philosopher and philologist M.M. Bahtin (1984) who brought the notion of dialogism and the concept of polyphony (multiple voices) into literary studies. Analyzing Dostoevsky's works, he focused on the way ideas are represented, special use of language, emphasized the relations between the author, his work, and readers in particular social and historical environment. The ideas of M.M. Bahtin (1984) were introduced to European research circles by J. Kristeva (1986), who used the term intertextuality speaking about the intersection of words or texts (Kristeva, 1986).

The notion of intertextuality has been considered from different perspectives. The most representative groups are scholars from literary semiotics J. Kristeva (1980), D. Chandler (2017) and scholars from discourse analysis and critical discourse analysis group N. Fairclough (1992, 1995), Ch. Bazerman (2004), H.D. White (2000).

From the semiotic perspective of intertextuality, the text is referred to as having dynamic coordinates or axes, which run from the writer to the reader and through texts and contexts (Kristeva, 1980).

The analyses of discourse intertextuality deal with linguistic and social aspects, taking into consideration both explicit and implicit manifestation of intertextuality (Wodak, 2011). In Discourse Analysis the concept of intertextuality is important in analyzing discourse practices as they manifest in the versatility of texts, meaning, form and style (Fairclough, 1992). The approaches to intertextual analysis differ, focusing on language use in social contexts, forms and functions of intertextuality and describing the explicit and implicit use of intertextual devices.

The analysis of intertextuality in specialized discourse has been the main area of research in the works of V.K. Bhatia (2010), V.K. Bhatia and A. Bhatia (2011), A. Devitt (1991), Ch. Bazerman (2003), A. Martinez (1996), H. Sierochka (2014) and others. The basic concepts of analysis outlined by Ch. Bazerman (2003) concern the levels of intertextuality, techniques of intertextuality representations, intertextual distance, and translation across contexts. An important factor in the analysis of intertextuality has understood what intertextual devices are and the way they function. The review of intertextual analyses of legal texts revealed that the studies have been not numerous, but provided important results and outlined perspectives and approaches to further research.

Intertextuality is one of the distinctive features of legal discourse. Intertextual relations are various and complicated and could create obstacles to communication. The analyses of intertextuality in legal discourse was intended to study how intertextuality enhances effectiveness in specialist communication and contributes to professional discourse acquisition. V.K. Bhatia (1998) reported that analysis of the legislative texts based on the British Housing Act showed that intertextual links served not only cohesive function with preceding legislation but revealed four major

XLinguae, Volume 11 Issue 1, January 2018, ISSN 1337-8384, eISSN 2453-711X 
types of intertextual devices, performing the following functions: signalling textual authority, providing a terminological explanation, facilitating textual mapping and defining legal scope.

Analysis of specialized texts in the sphere of tax accounting provided by A. Devitt (1991) was aimed at describing intertextual relations of this genre with other genres and how those texts interact in particular community. As it was shown the texts analyzed, including letters to clients and taxing authorities, memoranda, tax protests, etc., have been used to perform particular functions of this profession. Though this genre is not purely legislative, it has strong intertextual relations with the legal tax code. The interaction of texts within a profession indicates in what way some professions could be dependent on texts and writing.

The importance of law and legal texts in various communities substantiates the necessity of studying intertextual relations.

\section{Materials and Methods}

The study of intertextual relations in the judgment of the Court of Appeal, their forms, and functions, provides insight into linguistic, social and cultural aspects of intertextuality.

The court judgment is a written formal decision which performs an important authoritative function, resolving conflicts and regulating relations in society. The text of the judgment is specific in its form, functions, and language. A court judgment is defined in the legal dictionary as "a decision made by a court or other tribunal that resolves a controversy and determines the rights and obligations of the parties" (The free dictionary by Farlex, 2008). The other definition, provided by the same dictionary, details the following aspects "the final decision by a court in a lawsuit, criminal prosecution, or appeal from a lower court's judgment except for an 'interlocutory judgment' which is tentative until a final judgment is made" (The free dictionary by Farlex, 2008). There are some requirements which specify the structure and functions of judgment. It must be in writing; it signifies the end of the court jurisdiction in the case. It must show that all the issues have been adjudicated and indicate the parties for and against whom it is given. There could be different types of judgment depending on legal system requirements.

The judgments in the court of appeal differ from the judgments of other courts. The Court of Appeal is in the intermediate position between trial courts and the Supreme court within the court system. The main function of the court of appeal is to review the decisions of lower courts dealing with facts that were objected to or argued in the lower court, with no new evidence being presented. So, the court of appeal reviews the trial court's application of the law.

The judgments of the court of appeal have been chosen for the analysis as they are based on a review of previous decisions and law applied by the trial court, and show the close interrelations between both courts' decisions and all texts mentioned. As the parties to the case are affected by these decisions, they are also involved into these interrelations, but at the social and cultural levels.

As the court of appeal reviews the trial court decision, the judgment of the court of appeal represents an analysis of all legal texts that had been referred to in the previous judgment and included new references which are relevant to the appeal. The interrelations between all these texts are the essence of the appeal process.

To describe these relations, we have to proceed to the analysis of the judgment of the Court of Appeal (Civil Division), the UK, on the appeal from the High Court of Justice, Queen's Bench Division in the case between Google Inc. and the claimant (Court of Appeal Judgment, 2015). Examples provided in these studies have been taken from the judgment mentioned above. 


\section{Results and Discussion}

It is necessary to mention that the judgment as a specific genre has its distinctive features and structure. The text is usually divided into paragraphs, for example, the text under study is composed of numbered 142 paragraphs. That is why if there is a reference to a text from a particular paragraph the number of the paragraph is kept in the reference.

The analysis made clear that every paragraph of the court of appeal judgment is related to some particular text or texts. The references are made to these related texts (usually previous cases, court decisions, Acts or sections of acts, opinions, etc.), or to some parts of the current judgment. As the following example shows it is possible to come across the reference being made to the external text and a particular part of the judgment, in this case, we can speak about external and internal intertextual relations:

"Personal data" for the DPA is defined in section 1(1) of the DPA: see para 52 above" (Court of Appeal judgment,2015).

Here the DPA stands for the Data Protection Act. Studying the types of reference, used in the judgment, the following most frequent intertextual devices have been identified such as citation, general reference, multiple references, direct speech and reported speech and paraphrasing. All these types of references could be attributed to explicit intertextuality; implicit intertextuality could also be present in the judgment. The following statement of the judge exemplifies the use of implicit intertextual relations when no particular texts have been mentioned, but their availability and relevance are implied:

The issue of classification or nomenclature has been the subject of some discussion in the cases, and amongst academics (ibid.).

The identified types of intertextual devices specific to the court of appeal judgment are language units or acts which are used to relate judgments to other texts showing that court judgments are fair, legally grounded, have a solid base and derive from legal practice. Court judgments are based on detailed interpretation of law and abundant in citations. It has been claimed that intertextuality does not require citing punctuation (Ivanic, 1998). Thus one might think that citation could be denied in intertextual relations. In the sphere of law, a citation constitutes an important part of legal writing, and as it can be seen in court judgments. Citation in legal discourse is the act of referring to a legal authority, the statute, the case, legal textbook and others. The citation is very specific to legal texts, has to follow strict requirements, differs from a citation in other discourses and is known as a legal citation. In some countries, the standards of legal citation have been devised and used (OSCOLA, 2006). In the discourse of case law system, the citation has a particular linguistic form containing specific abbreviations, provides detailed information for locating the referred case within the collections of court reports. Legal citation is one of the most frequently used forms of intertextual devices in legal discourse:

Sir Anthony Clarke MR made similar observations in Murray v Big Pictures (UK) Ltd [2008] EWCA Civ 446; [2009] Ch 481 at para 24: "The principles stated by Lord Nicholls [in Campbell] can we think to be summarised in this way...” (ibid.)

Another type of reference to legal texts concerns the type of reference which does not mention exact details of the text sources apart from general information such as the case name or the section or the title of the document, it only points to or names a

XLinguae, Volume 11 Issue 1, January 2018, ISSN 1337-8384, eISSN 2453-711X 
particular relevant text. For intertextual analysis this type of reference could be described as general or nominating reference:

Mr. White's secondary position is that, even if Douglas $v$ Hello (No 3) is not binding on us, the views expressed in that case are correct (ibid.).

The use of the direct and reported speech is specific to this genre of legal texts, and these language forms could be identified as intertextual devices, having particular forms and functions:

He said: "54. Judges commonly adopt one or both of two approaches to..."

First, he says that the Charter does not expand rights afforded under EU law(ibid.).

Another device used in court judgment is Paraphrasing. Paraphrasing has been used to relate to other legal texts or opinions at a less formal level and which make the language of the judgment more comprehensible:

On a literal interpretation of section 13(2), an individual who suffers distress because of a contravention by a data controller of any of the requirements of the DPA is entitled to compensation only if...(ibid.).

The legal texts including judgments are abundant in references, these references are often multiple or mentioned in particular sequence. This sequence could serve for contrasting, comparing or consolidating information. This type of reference could be outlined as multiple references to emphasize the specific functions of intertextual relations. As it can be seen in the following example the problem came from contradicting legislation:

The problem the courts have had to grapple with during this period has been how to afford appropriate protection to 'privacy rights' under article 8 of the Convention, in the absence (as was affirmed by the House of Lords in Wainwright $v$ Home Office [2004] 2 AC 406) of a common law tort of invasion of privacy (ibid.).

The types mentioned above of intertextual devices are used to perform various functions in the text of the judgment. The main types and functions of the intertextual devices have been outlined in Table 1, made by the authors; examples are taken from the judgment mentioned above (Court of Appeal Judgment, 2015).

Table 1: Types and functions of intertextual devices

\begin{tabular}{|l|l|l|}
\hline $\begin{array}{c}\text { Types of Intertextual } \\
\text { devices }\end{array}$ & \multicolumn{1}{|c|}{ Forms } & \multicolumn{1}{|c|}{ Functions in the text } \\
\hline Legal Citation & $\begin{array}{l}\text { Sir Anthony Clarke MR } \\
\text { made similar observations } \\
\text { in Murray v Big Pictures } \\
\text { (UK) Ltd [2008] EWCA }\end{array}$ & $\begin{array}{l}\text { To provide authority } \\
\text { To review previous } \\
\text { judgment } \\
\text { To refer to particular } \\
\text { legislation 446; [2009] Ch. 481 } \\
\text { at para 24:... }\end{array}$ \\
& $\begin{array}{l}\text { To follow the precedent } \\
\text { To refer to other case } \\
\text { reasoning principal questions } \\
\text { The arise under the first }\end{array}$ \\
& $\begin{array}{l}\text { To introduce legislation } \\
\text { issue are (i) whether the } \\
\text { decision in Johnson v } \\
\text { Medical Defence Union is }\end{array}$ & \\
\hline
\end{tabular}




\begin{tabular}{|c|c|c|}
\hline & $\begin{array}{l}\text { authority binding on this } \\
\text { court }\end{array}$ & \\
\hline General Reference & $\begin{array}{l}\text { Section } 13 \text { provides: "( } 1) \\
\text { An individual who suffers } \\
\text { damage because of any } \\
\text { contravention by a data } \\
\text { controller of any of the } \\
\text { requirements of this Act is } \\
\text { entitled to compensation } \\
\text { from the data controller } \\
\text { for that damage. } \\
\text { Section 55A(1) gives the } \\
\text { Information } \\
\text { Commissioner the power, } \\
\text { where subsection (2) or } \\
\text { (3) applies, }\end{array}$ & $\begin{array}{l}\text { To review previous } \\
\text { judgment } \\
\text { To refer to another case } \\
\text { For precise information } \\
\text { To provide authority }\end{array}$ \\
\hline Multiple Reference & $\begin{array}{l}\text { Secondly, Mr. White } \\
\text { submits that section } 13 \text {, } \\
\text { read together with } \\
\text { sections } 40 \text { and 55A of } \\
\text { the DPA, is sufficient to } \\
\text { constitute an effective } \\
\text { remedy. }\end{array}$ & $\begin{array}{l}\text { To consolidate information } \\
\text { To contrast information } \\
\text { To compare information } \\
\text { To clarify }\end{array}$ \\
\hline Direct speech & $\begin{array}{l}\text { Lord Nicholls said this at } \\
\text { para 255: "As the law has } \\
\text { developed breach of } \\
\text { confidence or misuse of } \\
\text { confidential information, } \\
\text { now covers two distinct } \\
\text { causes of action... } \\
\text { He then said at para 80: } \\
\text { "However, and } \\
\text { additionally, there are } \\
\text { substantial grounds, not } \\
\text { affected by either of those } \\
\text { issues, why the appeal } \\
\text { must fail in any event. }\end{array}$ & $\begin{array}{l}\text { To state facts } \\
\text { To give opinion } \\
\text { To refer to other judge } \\
\text { reasoning/observation } \\
\text { To review and analyse }\end{array}$ \\
\hline Reported Speech & $\begin{array}{l}\text { The claimants allege in } \\
\text { respect of their claims for } \\
\text { misuse of private } \\
\text { information and breach of } \\
\text { confidence,... } \\
\text { In those circumstances, he } \\
\text { said, the focus was not on } \\
\text { the duty of good faith } \\
\text { applicable to confidential } \\
\text { personal information and } \\
\text { trade secrets alike, but... }\end{array}$ & $\begin{array}{l}\text { To allege smth } \\
\text { To review judge reasoning } \\
\text { To review other judgment }\end{array}$ \\
\hline
\end{tabular}

XLinguae, Volume 11 Issue 1, January 2018, ISSN 1337-8384, eISSN 2453-711X 


\begin{tabular}{|c|c|c|}
\hline & $\begin{array}{l}\text { He then considered } \\
\text { whether to refer to the } \\
\text { European Court of Justice } \\
\text { and declined to do so. }\end{array}$ & \\
\hline Paraphrasing & 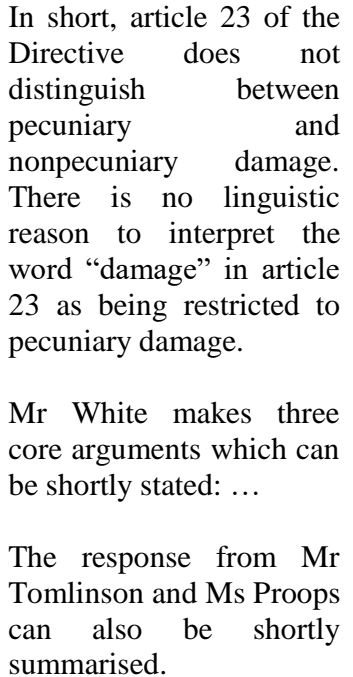 & $\begin{array}{l}\text { To generalise } \\
\text { To outline briefly } \\
\text { To comment on } \\
\text { To summarise }\end{array}$ \\
\hline
\end{tabular}

As it can be seen from the analysis, the court of appeal proceeds to the final decision through the web of intertwined intertextual relations. The theory of Intertextuality provides approaches to deal with the complexity of this genre of legal discourse. Intertextual analysis contributes to more effective reviewing of court judgment and communication in the court. Specificity of intertextual relations of legal discourse is defined by various social, cultural and professional factors which are important to the community.

\section{Conclusion}

The notion of intertextuality has been important in comprehending the complexity of specialized discourse. The analysis of a judgment of the Court of Appeal, a particular genre of legal discourse, has substantiated the view that the text of the court judgment depends greatly on intertextual relations. While reviewing the previous court decision, the court of appeal has to relate to the trial court's judgment, legislation, legal textbooks, opinions, etc. The structure of the court of appeal judgment is defined to some extent by intertextual relations. Thus, the text of the judgment is divided into paragraphs which have strong links with particular texts. These intertextual relations are manifested in various forms and functions. The intertextual devices, widely used in the court of appeal judgment, are the following: legal citations, general reference, multiple references, direct and reported speech, and paraphrasing. Some intertextual devices which are typical to the court of appeal judgments are not found in other genres such as legal citation; other devices acquire particular functions such as paraphrasing and multiple references. The most important functions that the intertextual devices perform have been identified as the following: referential, reviewing, consolidating, stating or introducing facts, contrasting or comparing information, alleging and others. Among them reviewing function is the most frequently used and attributed to various intertextual devices, this fact proves that intertextual relations are manifested not only at the text level but continue in the 
discourse and social practices. Intertextual relations could not be fully comprehended without their study at various levels linguistic, social and cultural. Intertextual relations in court judgments go far beyond the professional circles and are related to many important social and cultural spheres. Intertextual relations in law discourse provide for continuity of law and social stability.

\section{Acknowledgements}

The publication was prepared with the support of the RUDN University program 5100.

\section{Bibliographic references}

BAHTIN, M.M. 1984. Problems of Dostoevsky's Poetics. In: Theory and History of Literature. Volume 8. Minneapolis: University of Minnesota Press. ISBN 0-81661227-7.

BAZERMAN, CH. 2003. Speech Acts, Genres, and Activity Systems: How Texts Organize Activity and People. In: What writing does and How it Does It: An Introduction to Analyzing Texts and Textual Practices. Bazerman Ch., Prior, P. (Eds.). New Jersy: Routledge. ISBN 1-4106-0952-9.

BHATIA, V.K. 1998. Intertextuality in Legal Discourse. In: The Language Teacher, vol. 2, n. 11. ISSN 0287-2420. Available online: http://jaltpublications.org/old_tlt/files/98/nov/bhatia.html

BHATIA, V.K. 2010. Interdiscursivity in professional communication. In: Discourse and Communication, vol. 4, n. 1, pp. 51-67. ISSN 1750-4813.

BHATIA, V.K. - BHATIA A. 2011. Legal discourse across cultures and sociopragmatic contexts. In: World Englishes, vol. 30, n. 4, pp. 481-495. ISSN 1467-971X. CHANDLER, D. 2017. Semiotics: The Basics. New York: Routledge, Kindle Edition. 273 p. ISBN-13 978-0415363754. ISBN-10 0415363756.

COURT OF APPEAL JUDGMENT. 2015. EWCA Civ 311. Available online: https://www.judiciary.gov.uk/wp-content/uploads/2015/03/google-v-vidal-halljudgment.pdf

DEVITT, A. 1991. Intertextuality in Tax Accounting: Generic, Referential, and Functional. In: Textual Dynamics of the Professions: Historical and Contemporary Studies of Writing in Professional Communities. Bazerman, C., Paradis, J. (Eds.). Madison: University of Wisconsin Press, pp. 336-357. ISBN 0-299-12540-4. ISBN: 0-299-12594-7.

FAIRCLOUGH, N. 1992. Intertextuality in Critical Discourse Analysis. In: Linguistic and Education, n. 4, pp.269-293. Available online: http://www.sciencedirect.com/sdfe/pdf/download/eid/1-s2.0-

089858989290004G/first-page-pdf

FAIRCLOUGH, N. 1995. Media Discourse. London: Hodder Arnold Publication. ISBN-10 0340588896.

IVANIC, R. 1998. Writing and identity: The discoursal construction of identity in academic. Amsterdam: John Benjamins Publishing Co. ISBN 9789027217974.

KRISTEVA, J. 1986. Word, Dialogue and Novel. In: The Kristeva Reader. Moi, T. (Ed.). New York: Columbia University Press. ISBN 0-631-14931-7.

KRISTEVA, J. 1980. Desire in Language: A Semiotic Approach to Literature and Art. New York: Columbia University Press. ISBN 978-0-231-04807-1.

OSCOLA. 2006. Available online: https://www.law.ox.ac.uk/sites/files/oxlaw/oscola_2006.pdf

THE FREE DICTIONARY BY FARLEX. 2008. Available online: https://legaldictionary.thefreedictionary.com/judgment 
WHITE, H. D. 2011. Relevance Theory and Citations. In: Journal of Pragmatics, vol. 43, pp. 3345-3361. ISSN 0378-2166.

WODAK, R. 2011. Critical Discourse Analysis. In: Continuum Companion to Discourse Analysis. Hyland, K., Paltridge, B. (Eds.). London: Continuum, pp.311326. ISBN: 9781441165640.

Words: 3897

Characters: 26028 (14,46 standard page)

Assoc. Prof. Natalia N. Udina, $\mathrm{PhD}$

Law Institute

Foreign Languages Department

Peoples' Friendship University of Russia - RUDN University

6 Miklukho Maklay st.

117198 Moscow

Russia

udinann@gmail.com

Assoc. Prof. Alexey B. Kostromin, PhD

Law Institute

Foreign Languages Department

Peoples' Friendship University of Russia - RUDN University

6 Miklukho Maklay st.

117198, Moscow

Russia

costromin@yandex.ru

Assoc. Prof. Kamo P. Chilingaryan

Law Institute

Foreign Languages Department

Peoples' Friendship University of Russia - RUDN University

6 Miklukho Maklay st.

117198 Moscow

Russia

chili1@yandex.ru

Assoc. Prof. Elena P. Kalashnikova

Law Institute

Foreign Languages Department

Peoples' Friendship University of Russia - RUDN University

6 Miklukho Maklay st.

117198 Moscow

Russia

ekalaschnikowa@mail.ru 